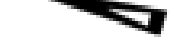

Australian Journal of
Educational Technology

\title{
Managing the development and production of interactive multimedia courseware in education
}

\author{
Annie Y. W. Nicholson \\ Hong Kong Institute of Education \\ Johnson Y. K. Ngai \\ Curriculum Development Institute
}

\begin{abstract}
Multimedia technology has advanced significantly in the past few years. Graphic, animation, audio and video data can be stored and processed efficiently in personal computer systems. CD-ROM technology has also matured over the years and it provides an economical and convenient means for storing a large amount of digital information. With careful designing and authoring, interactive multimedia courseware, in CD-ROM format, can be developed and produced for effective learning.
\end{abstract}

In developing interactive multimedia courseware for teaching and learning, instructional design (ID) and management are two crucial aspects for successful products. Based on the authors' experiences in developing multimedia projects in areas (a) curriculum information system, (b) interactive desktop video and (c) video CD-ROM courseware, a design model for managing interactive multimedia courseware production has been proposed.

This paper will present and discuss the model which includes 5 phases, namely (1) analysis, (2) development, (3) production, (4) evaluation, and (5) implementation.

The impact of both hardware and software developments in video technology, computer technology, telecommunications and their related fields has been significant in 1980s and 90s. These technologies move towards the trend of digital convergence, which is significant for present and future development. It has created a digital platform which brings the audio-visual technology, computer technology and telecommunications together. This convergence holds the key to the electronic future, the interactive desktop video and the information superhighway (Nicholson \& Ngai, 1995).

The development in the following areas has major impact on production of courseware, which is the generic term used for educational software and related paper materials. 
- Desktop video provides the capability to store video data in digital format, and supports the playback in a microcomputer.

- Compression and decompression (CODEC) technology overcomes the problems of large file size of video digital data.

- Multimedia technology creates, stores, transmits and retrieves text, graphic, sound, animation and video images.

- $C D-R O M$ supplies a long lasting, stable medium for storage of a very large amount of data.

One of the many ways to make use of the potential of these developments in education is the production of interactive multimedia courseware for teaching and learning. This courseware takes the advantages of the latest technology by creating a lively, stimulating and interactive multimedia learning environment, incorporating text, colourful computer graphics, animation and full motion video on screen. This capability helps to promote interest in learning. In addition, individualised learning materials are particularly suitable for students of different learning abilities, as students can work at their own pace. With built-in interactive exercises and learners' self assessment, independent learning can also be encouraged.

\section{Experiences to be shared}

Since 1993, the authors have been conducting a number of projects on the development of new technologies in education in areas of (a) curriculum information system, (b) interactive, desktop video, and (c) video CD-ROM courseware. The following is a discussion on the features of these projects.

\section{A Curriculum Information System: Cataloguing. Indexing and Retrieval of Multimedia Resource Materials in CD-ROM format}

In order to help local teachers and educators to locate curriculum resource materials efficiently and effectively, an information database on cataloguing, indexing and retrieval of multimedia resource materials, in CD-ROM format, was developed (Nicholson and Ngai, 1994b). It is designed to support users in their search for information. The database has incorporated built-in functions of data entry and retrieval. It is text-based, menu driven and user friendly. It can also be adapted to put on a network.

There are two main characteristics of the system: (1) the incorporation of "non-traditional" library materials (White, 1984), and (2) the incorporation of locally produced materials in both Chinese and English. The "nontraditional" materials incorporated in this System include materials that are considered "ephemeral", such as reports and newsletters; and unpublished teaching and learning materials, such as worksheets prepared by teachers. Locally produced materials include items such as the publications developed by the Hong Kong Education Department and other local institutes. 
2. An Interactive Video CD-ROM on "Nicki's Adventure", a Primary 6 ETV English Language Programme, Windows AVI version and Windows MPEG version

The second project makes use of the development of desktop video. An existing curriculum resource kit was "converted" into an interactive multimedia courseware and was stored in a video CD-ROM. The original kit includes (a) an ETV English Language program for primary 6 pupils, titled "Nicki's Adventure", (b) Teachers' Notes; and (c) a set of pupils' worksheets. Two versions were produced: the Windows AVI version (Nicholson \& Ngai, 1994c) and the Windows MPEG version (Nicholson \& Ngai, 1994d). The advantages and limitations of the two versions were compared in terms of the complexity in producing the courseware, the convenience for users, and the quality in playing back the program.

The authoring software Authorware Professional for Windows was used to develop the interactive courseware. By using authoring software, the complexity and thus the cost of developmental work was reduced. The process in developing the courseware involved many stages: needs analysis, budgeting and scheduling, program structure (program flow) design, storyboarding, design of user interface, preparation of raw data (graphic, audio and video data), writing the courseware, evaluation, revision, and recording data into $\mathrm{CD}-\mathrm{ROM}$. The design of the courseware aims to motivate learners through multi-sensory interaction and participation.

3. Natural hazard: Earthquake. An Interactive Multimedia Courseware for Teaching and Learning Geography at HKCE Level, a video CD-ROM in Windows AVI version

The third project involves the design and development of a topic "Earthquake" in the subject Geography at the Hong Kong Certificate of Education Examination (HKCE) at Secondary 4 to 5 level (Nicholson \& Ngai, 1996a). The project aims to complement and supplement teaching and learning, and to make studying an examination topic more interesting. Past examination questions are also included for the convenience of teachers and students. Animation, newspaper clippings and TV news are part of the sources of information. The courseware is designed to promote learning of higher order cognitive objectives.

Hypermedia technology is used in developing the courseware. It consists of networks of related text, graphic materials, digital audio files and video clips through which users navigate using icons or search strategies. Keywords are linked in a nonlinear manner. 
4. Design, development and evaluation of a series of multimedia CD-ROMs for Learning English, Windows version

This project is currently being developed. It sets out to research, design, develop and evaluate resource materials, in interactive multimedia in CDROM format, to help Primary 6 to Secondary 1 students of different learning abilities to acquire basic competency in English language, so that they can learn effectively in classes using English as the medium of instruction in Secondary. During this bridging process, students of all abilities need to master confidently basic competency in independent learning and language skills such as reading, writing, listening and dictionary skills (Curriculum Development Institute, 1995).

The aims of this Project are to improve motivation for language learning, and to supply quality materials for learning English. Some of the objectives are (a) to design a series of interactive multimedia resource materials for the acquisition of basic competency in English Language; (b) to design and produce CD-ROMs to support students to learn English in a self-learning mode; (c) to produce supplementary materials in traditional formats, such as printed guidelines, sound tracks and video segments; (d) to conduct formative and summative evaluation on learning effectiveness of these materials; and (e) to research implementation and alternative uses of these CD-ROMs. High quality audio capability is particularly important for listening and correct pronunciation. Inclusion of video segment increases the lifelike situation and make language learning materials more realistic and functional.

\section{Common Acids and Alkalis: An Interactive Multimedia Courseware for Teaching and Learning Chemistry at HKCE Level, a video CD-ROM in Windows AVI version}

This is an on-going project, aiming to develop interactive self-access learning materials for chemistry students at the Secondary 4 to 5 levels. This courseware makes use of the advantages of multimedia to make learning topics which are more academically inclined interesting. The design will help students (a) to acquire knowledge; (b) to apply this knowledge in daily life; (c) to develop ability to solve problems, and (d) to think scientifically and independently, and (e) to relate scientific knowledge to its social, economic, environmental and technological implications (Curriculum Development Council, 1991).

This courseware will be developed in "an Internet environment". Internet is a network of a large number of networks around the world. With an World Wide Web (WWW) browser software, it is easy to search for various kinds of information. It also has the advantage in disseminating information and providing a channel for communication among users. The user interface of the WWW browser is graphical and easy to use. It is 
primarily based on HTML (Hypertext Markup Language) and is developed to support further interactivity and multimedia.

To enable Internet to be multimedia and interactive, Visual Basic Script by Microsoft and Java Script by Sun Microsystems have been implemented in the next release of WWW browser software. For example, Microsoft Internet Explorer 3.0 will support Visual Basic Script. Based on Visual Basic Script or Java Script, interactive and multimedia courseware can be stored on the Internet. Via Internet, prototype testing and evaluation of courseware can be conducted. Other useful information on effectiveness of courseware being developed can also be collected from users including teachers and learners on the Internet.

\section{Developing instructional multimedia projects}

Developing interactive multimedia courseware for teaching and learning can be a very complex task. Complexity includes:

- a wide range of theories, knowledge and skills

- the challenge of ever-improving technology

- a team of diverse expertise, and

- the tension among educational purposes, entertainment and resources.

Complexity in developing multimedia products results from the fact that it derives theories, knowledge and skills from many disciplines or fields of studies, such as cognitive psychology, perception psychology, measurement, evaluation, communications, management, media, computer science and systems engineering. Technology itself is continually updating and improving. New products, always advertised as more powerful, appear in the market nearly every other day. New "tools" can be very complex, and have to be studied and applied. In addition to all these, development of instructional multimedia materials faces the tension among educational purposes, entertainment and resources. Funding for educational projects is always limited. The producers should never lose sight of the learning objectives, and give way to fun. Maintaining the balance between arousing interest and achieving learning effectiveness is most challenging.

Developing multimedia projects needs a diverse range of expertise, including professionals in education and technology. Key personnel comprise of (a) content developers, (b) instructional technologists, (c) media specialists in preparation of multimedia materials, $(\mathrm{d})$ courseware developers responsible for authoring and CD-ROM production. All work as a team, with contribution from areas of

teaching and learning

subject knowledge

video creation 
audio production

graphic design

computer programming

authoring

program evaluation

From the authors' experiences in going through the complexity in developing multimedia projects for teaching and learning, two aspects are considered to be specifically crucial for success: instructional design (ID) and management. Instructional design is highly creative process, developing materials that can make learning both interesting and effective. Bringing together and managing a team of personnel with different knowledge background, expertise, and different beliefs are no easy tasks. Managing people requires the leadership, commitment, abilities to motivate people, taking and implementing decisions, managing meetings, managing conflict, etc.

Conducting multimedia projects requires careful planning and management of resources. Resources can be classified as human, material and financial. "What is the most cost-effective way of achieving the goals?" is the principal question for an effective project manager. Fundamental to the success of investment decisions is that they are implemented in a planned way. On the cost side, there should be a budget against which the money is spent. More importantly, though, is that there should be evaluation on whether or not the investment has produced the products and benefits as predicted. Such evaluation presupposes that the expected benefits have been clearly stated in terms which are as measurable as possible.

\section{A design model for managing interactive multimedia courseware production}

To ensure the instructional appropriateness of the products and to incorporate the management dimensions in conducting multimedia projects, this paper proposes a design model for managing interactive multimedia courseware production (Figure 1). This model includes 5 phases, namely (1) analysis, (2) development, (3) production, (4) evaluation, and (5) implementation. 
support

development

content

learning methods

assessment strategies

learning environment

media choice

\section{Production}

design of courseware structure

preparation of raw data

encoding

authoring

technical testing

evaluation

structural evaluation

functional evaluation

opinions of users

analysis of cost effectiveness

monitoring

implementation

instruction-oriented

learner directed

Figure 1: A design model for managing interactive multimedia courseware production

\section{Analysis}

The first phase includes the analysis of a number of areas: (a) goals, (b) learners, (c) resources and constraints, and (d) support. To bring about effective teaching and learning requires careful planning. Stating the goals is an important part of planning. These goals identified should be related to what the target students should learn. Specific learning objectives and the design of the project should be developed according to these goals.

An overall plan for the project with the following sub-headings can be worked out at this stage: background to the project, aims and objectives, Overview of the design, products and outcome, dissemination of products, action plan, monitoring and evaluation procedures, budget, expertise and other support required. 


\section{Development}

Activities of the second phase comprise: (a) construction of content, (b) design of learning methods, (c) decisions on assessment strategies, (d) creation of the learning environment and (e) selection of media. These activities are based on the result of the analysis phase. There is no fixed sequence of conducting these activities.

The key personnel at this stage are the content developers including subject knowledge experts, curriculum experts, and instructional technologists. However, communication with media specialists and courseware developers throughout the process of content development is very important. This reduces the differences in opinions of all parties, and will facilitate the actual production of materials if the ideas of the content developers are fully understood by the production teams.

\section{Production}

The scale of production depends largely on the scale of the project and amount of the budget and resources available. The complexity of production process increases if video production is required. This phase involves: (a) the design of courseware structure, (b) preparation of raw data, (c) encoding, (d) authoring and technical testing. The following are some of the major areas of production:

- idea creation and overall design

- production of video segments (scripting, storyboarding, preparation of props and artist, location shooting, studio recording, post-production)

- production of audio segments (scripting, recording \& editing)

- preparation of computer graphics and animation

- design of courseware and interface

- authoring and programming

- encoding and recording

- designing and writing of guidelines

Technical testing and evaluation should be conducted throughout this stage to ensure quality production.

\section{Evaluation}

Both formative and summative assessment procedures are important in multimedia projects to evaluate the products produced, namely the courseware, the CD-ROMs and other supplementary materials. Criteria for evaluation involved are identified as follows (also see Nicholson \& Ngai, 1996):

- structural evaluation (assessment of structure and appearance of the courseware);

- functional evaluation (assessment of learning effectiveness); 
- opinions of users (students, teachers and other users' feedback, etc.)

- cost effectiveness (products against investment).

The main purposes of these evaluations are for courseware improvement and for subsequent development of guidelines/instructions for users. In order to evaluate the effectiveness of these materials, pre-test and post-test can be conducted.

Successful project development should also have monitoring processes built in. An advisory group, including developers, experts in various areas and users, can help to (a) advise on the project, (b) monitor progress of development, (c) ensure quality of the products produced, and (d) oversee the evaluation process. Developing projects for educational purposes, major clients' (such as practising teachers and students) opinions should never be ignored!

\section{Implementation}

Implementation can be defined as the process of putting into practice, emphasising on actual rather than assumed use (Nicholson, 1988, 1995). In using multimedia materials, there are at least two groups of users: the teachers and the students. Often for self-learning materials, the users are the learners, and the learning effectiveness can be assumed. However, if the users are teachers, they may modify the materials according to the objectives and context of the teaching and learning situation. In this case, it will be worthwhile to investigate how different teachers use the materials. Such information should be useful both for future development of instructional multimedia and for references for other teachers.

To study implementation and alternative use, teachers can be invited to review and try out the materials. Their use in schools can be observed and the teachers can be interviewed. Data collected can then be analysed, and possible alternative uses of the materials will be identified.

\section{Conclusion}

This paper aims to share the authors' experiences in developing multimedia projects, and to propose a model identifying different aspects in managing and producing multimedia products. To conduct complex multimedia projects, expertise from wide-ranging fields assembled in a team, in which tasks are to be completed by skilled and competent personnel in their respective disciplines. Finally, production of instructional courseware also faces the challenge of limited resources and funding. However, although there is always a limit in resources, there is no limit in creativity. It is up to us to produce materials with least resources and most creativity. 


\section{References}

Cooke, B. L. \& Nicholson, A. Y. W. (1993). Working With Groups. Teaching in Hong Kong: Developing Skills and Strategies Series, Longman.

Commission of European Communities (1991). Information and Communications Technologies in Europe. Directorate-General XIII Telecommunications, Information Industries and Innovation, Office for Official Publications of the European Communities.

Curriculum Development Council (1984). Syllabuses for Secondary Schools: Syllabus for Geography (Secondary 4-5). Hong Kong Education Department, Hong Kong Government Printer

Curriculum Development Council (1991). Syllabuses for Secondary Schools: Syllabus for Chemistry (Secondary 4-5). Hong Kong Education Department, Hong Kong Government Printer.

Curriculum Development Institute (1995). Bridging English Across Primary and Secondary Education. Hong Kong Education Department, Hong Kong Government Printer.

De Diana, I. P. F (1994). Aspects of Courseware Authoring. Journal of Computer Assisted Learning, 10(2), 65-67.

Galbreath, J. (1994). Multimedia in education: Because it's there? Tech Trends, 39(6), 17-20.

Langridge, D. (1991 ). Classifying Knowledge. In Meadows, J. (ed), Knowledge and Communication: Essays on the Information Chain. Library Association Publishing, Clive Bingley.

Lanzing, J. W. A. \& Stanchev, I. (1994). Visual aspects of courseware engineering. Journal of Computer Assisted Learning, 10(2), 69-80.

Nicholson, A. Y. W. (1988). A Study of the Implementation of a Curriculum Innovation in a Secondary School in Hong Kong: The case of F.I-III Social Studies. Unpublished MEd dissertation, University of Hong Kong.

Nicholson, A. Y. W. (1991). The pattern of media utilisation in secondary schools in Hong Kong. Paper presented in the In-College Block, Northern College of Education, Dundee, Scotland.

Nicholson, A. Y. W. (1995). Continuation of an innovation achieved? A case of ETV for Hong Kong schools. Proceedings of the International Curriculum Conference on Partnership in Curriculum Development: Towards More Effective Learning. Hong Kong Government Printer.

Nicholson, A. Y. W. \& Ngai, J. Y. K. (1994a). Interactive desktop video: From concept to prototype. Paper presented at the Hong Kong Educational Research Association (HKERA) Eleventh Annual Conference, Hong Kong.

Nicholson, A. Y. W. \& Ngai, J. Y. K. (1994b). A Curriculum Information System: Cataloguing, indexing and retrieval of multimedia resource materials (in CD-ROM format). Curriculum Development Institute, Education Department.

Nicholson, A. Y. W. \& Ngai, J. Y. K. (1994c). An interactive video CD-ROM on "Nicki's Adventure", a Primary 6 ETV English Language Programme (Windows AVI version), Curriculum Development Institute, Education Department.

Nicholson, A. Y. W. \& Ngai, J. Y. K. (1994d). An interactive video CD-ROM on "Nicki's Adventure", a Primary 6 ETV English Language Programme (Windows MPEG version), Curriculum Development Institute, Education Department.

Nicholson, A. Y. W. \& Ngai, J. Y. K. (1995). Understanding new development and applications of technology in education. Paper presented at the Hong Kong Educational Research Association (HKERA) Twelfth Annual Conference, Hong Kong. 
Nicholson, A. Y. W. \& Ngai, J. Y. K. (1996a). Natural Hazard: Earthquake. A multimedia interactive courseware for teaching and learning Geography HKCE Level, in video CD-ROM format, in World Wide Web version. Hong Kong Institute of Education and Curriculum Development Institute.

Nicholson, A. Y. W. \& Ngai, J. Y. K. (1996b). Converting a traditional multimedia kit into an interactive video CD-ROM. Journal of Educational Technology Systems, 24(3), 235-247. Baywood Publishing, New York.

Raskin, R. (1994). Creating multimedia to die for. PC Magazine, February, 209-251.

Schwier, R. A. \& Misanchuk, E. R. (1993). Interactive Multimedia Instruction. Englewood Cliffs, NJ: Educational Technology.

Vaughan, T. (1993). Multimedia Making It Work. Osborne McGraw-Hill. White, H. S. (1984). Managing the Special Library. Knowledge Industry Publications.

Annie Y. W. Nicholson is Senior Lecturer in the Department of Curriculum and Instruction at the Hong Kong Institute of Education. Tel 2817 1366, email anichol@nc.ied.edu.hk. Johnson Y. K. Ngai is the Senior Curriculum Officer with the Educational Technology Unit at the Curriculum Development Institute in Hong Kong. Tel 28925881.

Please cite as: Nicholson, A. Y. W. \& Ngai, J. Y. K. (1996). Managing the development and production of interactive multimedia courseware in education. Australian Journal of Educational Technology, 12(1), 35-45. http:/ / www.ascilite.org.au/ajet/ajet12/nicholson.html 